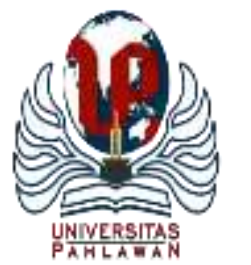

Edukatif : Jurnal Ilmu Pendidikan Volume 3 Nomor 6 Tahun 2021 Halm 5256 - 5264

EDUKATIF: JURNAL ILMU PENDIDIKAN

Research \& Learning in Education

https://edukatif.org/index.php/edukatif/index

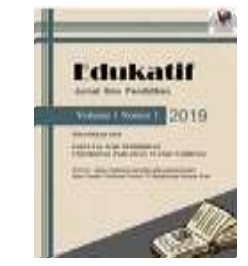

\title{
Pengukuran Mutu Pembelajaran di FKIP UNJA dalam Upaya Membangun Generasi Economic Citizen yang Mengelaborasi Program MBKBM Kemendikbud
}

\author{
Rosmiati $^{1 凶}$, Iwan Putra ${ }^{2}$, Ahmad Nasori ${ }^{3}$ \\ Universitas jambi, Indonesia ${ }^{1,2,3}$ \\ E-mail : $\underline{\text { rosmiatinnoer@yahoo.com }}{ }^{1}, \underline{\text { iwanputra@unja.ac.id }}{ }^{2}, \underline{\text { nasoriunja@ }}$ gmail.com $^{3}$
}

\begin{abstract}
Abstrak
Kebijakan yang dilakukan Fakultas Keguruan dan Ilmu Pendidikan Universitas Jambi dalam menghadapi Transisi Polemik Pandemi Covid 19 menyebabkan turbulensi dalam Kualitas Mutu Pendidikan. peneliti ini bertujuan untuk melakukan Pengukuran Mutu Pendidikan di FKIP Universitas Jambi dalam Upaya Membangun Generasi Economic Citizen melalui elaborasi Program MBKBM Kemendikbud. Metode Penelitian ini dilakukan melalui penelitian deskriptif dengan metode survey dengan mengajukan kuesioner.sampel penelitan ini berjumlah 372 Mahasiswa. Penelitian ini dengan menggunakan teknik analisis data kuantitatif dengan pendekatan deskriptif. Penerapan kurikulum MBKM di FKIP Universitsa Jambi ini mengenai kegiatan Asistensi Mengajar, mayoritas mahasiswa menjawab bahwa 46,65\% orang sangat setuju. Program MBKM membangun desa melalui kegiatan PHP2D 51,44\% setuju dan 44,09 \% sangat setuju terhadap rekognisi untuk pertukaran pelajar. Secara massif dan kuantitatif persepsi mahasiswa mengenai mutu pembelajaran dari penerapan MBKM di FKIP Universeitas Jambi pada dasarnya baik hal ini ditandai dengan keikutsertaan 17 Program Studi yang ada di FKIP Universitas Jambi dalam menstimulus peserta didiknya dalam mengikuti program tersebut.
\end{abstract}

Kata Kunci: Mutu Pembelajaran, MBKM, Economic Citizen

\begin{abstract}
The policy made by the Faculty of Teacher Training and Education, Universitas Jambi in the face of Transition Polemic Pandemic Covid 19 caused turbulence in the Quality of Education. This research aims to perform a Measurement of the Quality of Education at the faculty of education, the University of Jambi to Build a Generation of Economic Citizens through the elaboration of the Program MBKBM Kemendikbud. Methods this Research was conducted through descriptive research with survey method by submitting the questionnaire. The sample of this study amounted to 372 Students. This research is done by using the technique of quantitative data analysis with a descriptive approach. The implementation of the curriculum MBKM in guidance and counseling Universitas Jambi is about the activities of Assistance Teaching, the majority of students answered that $46.65 \%$ of people strongly agree. Program MBKM building village through the activities of PHP2D 51.44\% agreed that the da's $44.09 \%$ strongly agreed to the recognition for student exchange. Massive and quantitative perception of students about the quality of learning from the application of MBKM in guidance and counseling Universitas Jambi good it is characterized by the participation of 17 Study Programs at the faculty of education, the University of Jambi in stimulating the students to follow the program.
\end{abstract}

Keywords: Quality of Education MBKM, Economic Citizen

Copyright (c) 2021 Rosmiati, Iwan Putra, Ahmad Nasori

$\triangle$ Corresponding author:

Email : rosmiati_noer@yahoo.com

DOI : https://doi.org/10.31004/edukatif.v3i6.1356

ISSN 2656-8063 (Media Cetak)

ISSN 2656-8071 (Media Online)

Edukatif : Jurnal Ilmu Pendidikan Vol 3 No 6 Tahun 2021 p-ISSN 2656-8063 e-ISSN 2656-8071 
5257 Pengukuran Mutu Pembelajaran di FKIP UNJA dalam Upaya Membangun Generasi Economic Citizen yang Mengelaborasi Program MBKBM Kemendikbud - Rosmiati, Iwan Putra, Ahmad Nasori

DOI: https://doi.org/10.31004/edukatif.v3i6.1356

\section{PENDAHULUAN}

Berbagai macam kajian ilmiah menunjukkan bahwa skills mismatch, atau ketimpangan keterampilan dan mutu pembelajaran, di kalangan lulusan perguruan tinggi masih menjadi permasalahan dasar yang terus menghambat produktifitas dan daya saing berbagai sektor ekonomi dan industri di Indonesia dimasa Pandemi Covid-19 (Halaby, 1994; Pastore \& Zimmermann, 2019; Pellizzari \& Fichen, 2017; Senkrua, 2021). Seluruh dunia tak terkecuali di Indonesia mengalami goncangan secara siginifikan di segala bidang, termasuk di bidang pembelajaran akibat penyebaran virus covid 19. Melalui Siaran Konferensi Pers Melalui Media Masssa, Presiden Joko Widodo mengumumkan statut darurat Bencana nasional dari dampat COVID-19 yang melanda Negeri ini.

Berbagai kajian serupa juga merekomendasikan upaya yang harus dijajaki kampus untuk memperkuat relevansi pengajaran, pelatihan, dan pendidikan di perguruan tinggi dalam merespon polemik yang terjadi, tidak hanya mengenai aspek ekonomi dan tuntutan dunia kerja, namun juga tantangan sosial budaya dalam kehidupan bermasyarakat dan bernegara yang nantinya sebagai upaya membangun generasi economic citizen terdampak pandemic Covid-19 (A et al., 2020; B, 2020; Ratten \& Jones, 2021). Dalam hal ini, beberapa teori pengelolaan perguruan tinggi seperti the Triple Helix Model (Dzisah \& Etzkowitz, n.d.) telah merumuskan model hubungan mutual antara perguruan tinggi sebagai pusat pengembangan kompetensi manusia, dunia industri sebagai pengguna sumber daya manusia, dan pemerintah sebagai pembuat kebijakan yang mengatur peran kedua pihak lainnya.

Tantangan yang sama juga dihadapi oleh Fakultas Keguruan dan Ilmu Pendidikan Universitas Jambi selama masa pandemic Covid-19. Wabah COVID-19 memaksa model pembelajaran maju 10 bahkan 20 tahun lebih cepat. Konsep pembelajarang Daring tidak pernah terpikirkan bakal menjadi solusi utama dalam mengatasi Wanana polemic Pembelajaran di Negeri ini dan kini menjadi kebijakan utama pembelajaran nasional. Praktik Pembelajaran adaftif berbasis teknologi yang diterapkan sejak pertengahan Maret 2020 ini yang mengelaborasi program Kemendikbud memberikan pengalaman yang sangat berharga bagi semua pemangku kepentingan pendidikan. Karena Mutu Pembelajaran merupakan salah satu kelemahan Internal UNJA.

Kebijakan yang sama dilakukan Universitas Jambi dalam menghadapi Transisi Polemik Pandemi Covid 19 yang merupakan turunan kebijakan pada Fakultas Keguruan dan Ilmu Pendidikan yang menyebabkan turbulensi dalam Kualitas Mutu Pendidikan melalui penerapan pembelajaran Daring dengan E-Learning berbasis i-LMS yang mengelaborasi Program Kebijakan Kemendikbud. Kerumitan dan keguncangan pendidikan tidak lagi dianggap sebagai tantangan maupun ancaman, akan tetapi sebagai momentum transformasi dan adaptasi pendidikan digital. Hal ini dapat dilihat dari Pergeseran Mutu Pembelajaran diakibatkan Trasformasi Tekonologi sebagai berikut:

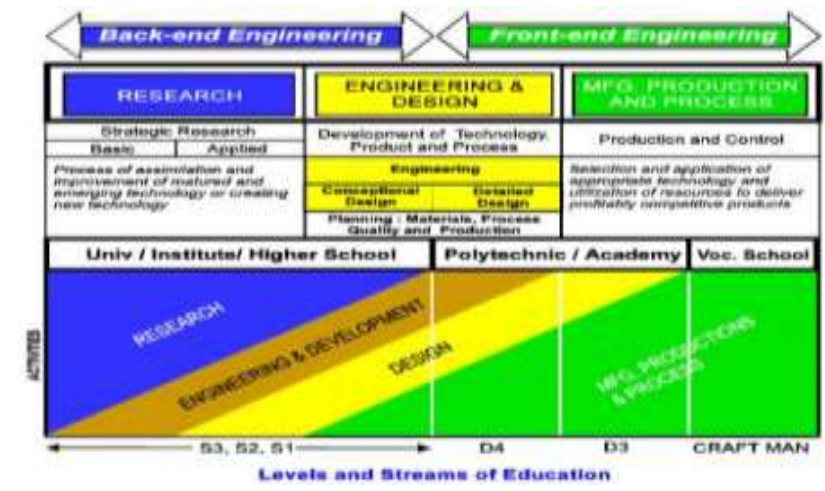

Gambar 1. Technological Process and Engineering Pipeline (Davies et al 2020)

Transformasi pendidikan digital yang mampu mengakomodasi sistem pembelajaran perkuliahan, 
5258 Pengukuran Mutu Pembelajaran di FKIP UNJA dalam Upaya Membangun Generasi Economic Citizen yang Mengelaborasi Program MBKBM Kemendikbud - Rosmiati, Iwan Putra, Ahmad Nasori

DOI: https://doi.org/10.31004/edukatif.v3i6.1356

menjamin hak-hak anak untuk belajar, menguatkan peran seluruh pemangku kepentingan dan mampu menjadi pusat literasi harus dirancang sedemikian rupa sehingga tidak menimbulkan kekacauan dan turbulensi sistem pendidikan (Iivari, Sharma, \& Ventä-Olkkonen, 2020; Maity, Sahu, \& Sen, 2021; Sá \& Serpa, 2020; Wright, 2020). Transformasi digital adalah cara paling aman untuk memutus penyebaran wabah corona. Mahasiswa mendapatkan hak untuk mendapatkan pendidikan, namun tidak mengabaikan kesehatan dan keselamatan jiwa. Oleh sebab itu, transformasi yang dilakukan secara cepat, dengan perencanaan yang memadahi sangat penting dilakukan.(Arora, Goyal, Chintalapudi, \& Mittal, 2020; Dutta, 2020; Martín, Acal, Honrani, \& Estrada, 2021)

Adaptasi dan transformasi pendidikan ini menjadikan kunci keberhasilan untuk menghadapi situasi wabah. Untuk itulah peneliti pengujian dengan melakukan Pengukuran Mutu Pendidikan di FKIP Universitas Jambi dalam Upaya Membangun Generasi Economic Citizen melalui elaborasi Program MBKBM Kemendikbud (Evaluasi Model Pembelajaran Adaptif dengan berbasis Teknologi dalam Menghadapi Transformasi Pendidikan Digital Masa Covid-19).

\section{METODE PENELITIAN}

Metode Penelitian ini dilakukan melalui penelitian deskriptif dengan metode survey (Anggito et al, 2018) dengan mengajukan kuesioner terhadap Mahasiswa FKIP Universitas Jambi Angkatan 2018-2020 yang mengalami pembelajaran secara Daring Dari Transformasi Pembelajaran Digital melalui Elaborasi Program Kemendikbud dari Bulan Maret Hingga Desembe 2020. Responden dipilih secara acak dan proporsional (proportionate stratified random sampling) dari jumlah Mahasiswa secara Keseluruhan sebanyak 5.360 orang yang Peneliti Peroleh dari Siakad Unja.

Untuk menentukan besarnya sampel dari populasi yang diambil, peneliti menggunakan rumus Slovin, sampel penelitan ini berjumlah 372,22 dibulatkan menjadi 372 Mahasiswa FKIP UNJA Angkatan 2018-2020. prosedur teknik daalam pelaksanaan Penelitian Survey, yaitu: a. Merumuskan masalah penelitian dan menentukan tujuan survei. b. Menentukan konsep dan hipotesa serta menggali kepustakaan. c. Pengambilan populasi dan sampel. d. Pembuatan kuisioner dan instrumen-instrumen. e. Perkerjaan lapangan, termasuk memilih dan melatih pewawancara. f. Pengolahan data. g. Analisis dan pelaporan (Hox \& Dillman, 2012). Didalam menjalankan Penelitian ini yang menggunakan Metode Survey menggunakan 3 Tipe Data yakni pengetahuan, sikap dan tindakan. Data mengenai Sikap dan tindakan diperoleh melalui 3 sumber yaitu Dosen, Tendik, dan Mahasiswa.

Didalam melakukan penelitian survey mengenai pengukuran kualitas mutu pembelajaan didalam penelitian ini dengan menggunakan teknik analisis data kuantitatif dengan pendekatan deskriptif. Penjelasan mengenai Prosedur Pendekatan penelitian yang digunakan bersumber dari data Primer melalui pemetaan Paradigm Post positif dari hasil design perancangan Ilmu Pengetahuan (seperti pemikiran tentang sebab akibat, reduksi kepada variable, hipotesis, dan pertanyaan spesifik, menggunakan pengukuran dan observasi, serta pengujian teori), semua komponen menggunakan standar baku yang sama didalam penelitian ini baik itu eksperimen maupun survey yang menggunakan Informasi Data Statistik dalam Penyajiannya (Bethlehem, 2009)

Semua Informasi dari Data yang telah dihimpun kemudian dianalisis dengan menghitung perolehan nilai skor rata-rata (Mean), median (Me), modus (Mo), simpangan baku atau standar deviasi (SD) melalui penggunaan software SPSS 25 for pc version.

\section{HASIL DAN PEMBAHASAN PENELITIAN}

Didalam merancangan pengukuran Mutu penerapan MBKM di FKIP Universitas Jambi dalam penelitian ini pada dasarnya peneliti membatasi penelitian ini hanya menggunakan Metode Survey dengan penjelasan deskriptif kualitatif sebagai ulasannya melalui data dan phenomena yang terjadi melalui analisis terkait dengan Konsep Merdeka Belajar-Kamous Merdeka (MBKM) di pada masa Pandemi Covid 19 yang 
5259 Pengukuran Mutu Pembelajaran di FKIP UNJA dalam Upaya Membangun Generasi Economic Citizen yang Mengelaborasi Program MBKBM Kemendikbud - Rosmiati, Iwan Putra, Ahmad Nasori

DOI: https://doi.org/10.31004/edukatif.v3i6.1356

terjadi. Berikut drekapitulasi daftar lis kegiatan Program MBKM di FKIP Universitas Jambi yakni sebagai berikut:

Tabel 1

List Kegiatan Program MBKM di FKIP Universitas Jambi

\begin{tabular}{clrc}
\hline \multirow{2}{*}{ NO } & \multicolumn{1}{c}{ PROGRAM MBKM } & DILAKSANAKAN & $\begin{array}{c}\text { TIDAK/BELUM } \\
\text { DILAKSANAKAN }\end{array}$ \\
\hline 1 & Pertukaran pelajar, & $\sqrt{ }$ & $\mathrm{x}$ \\
\hline 2 & Magang/Praktik Kerja, & $\mathrm{x}$ & $\mathrm{x}$ \\
\hline 3 & Asistensi Mengajar di Satuan Pendidikan, & $\mathrm{x}$ & $\sqrt{ }$ \\
\hline 4 & Penelitian/Riset, & $\mathrm{x}$ & $\sqrt{ }$ \\
\hline 5 & Proyek Kemanusiaan, & $\mathrm{x}$ & $\sqrt{ }$ \\
\hline 6 & Kegiatan Wirausaha, & $\mathrm{x}$ & $\mathrm{x}$ \\
\hline 7 & Studi/Proyek Independen, & $\sqrt{ }$ & \\
\hline 8 & $\begin{array}{l}\text { Membangun Desa/Kuliah Kerja Nyata } \\
\text { Tematik }\end{array}$ & & \\
\hline
\end{tabular}

Tabel tersebut menjelaskan mengenai phenomena yang terjadi pada saat implementasi MBKM di FKIP Universitas Jambi. Dari 8 Program MBKM, FKIP Universitas Jambi baru menerapkan 3 skema kegiatan MBKM yakni melalui penerapan Pertukaran Pelajar, Asistensi Mengajar di Satuan Pendidikan serta Membangun Desa melalui PHP2D. Penjelasan secara rinci mengenai prosentase keterlaksaan masing-masing Program MBKM dapat dijelaskan melaui Grafik sebagai berikut

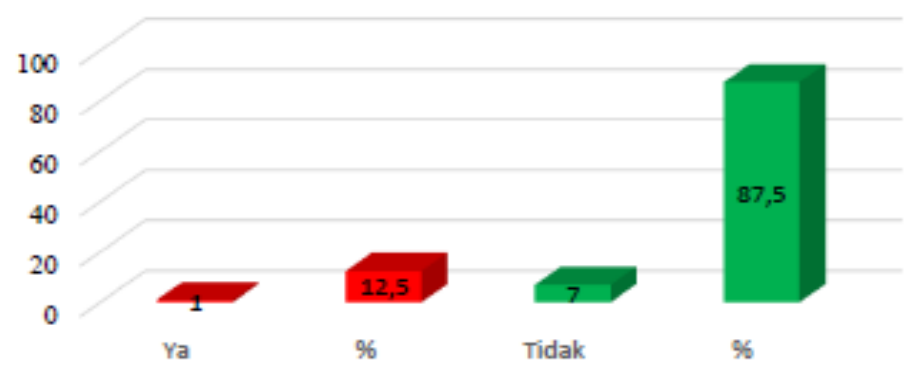

\section{Gambar 2. Program MBKM di FKIP Universitas Jambi}

Dari grafik diatas diketahui dari 8 program bahwa ada 3 program yang sudah dilaksanakan yakni asistensi mengajar di satuan Pendidikan atau sekitar 12,5 \%,, Membangun Desa/Kuliah Kerja Nyata(KKN Kebangsaan) atau sekitar 7\%, serta Pertukaran Pelajar atau sekitar $1 \%$ dan sebanyak 5 program belum dilaksanakan sekitar $87.5 \%$.

Pengukuran aspek keterlaksaan mutu Pendidikan ini dapat dilihat pada animo mahasiswa yang ada di FKIP Universitas Jambi dalam ikut serta mengikuti program peserta Asistensi Mengajar di Satuan Pendidikan sebagai bentuk adaptasi Kurikulum MBKM yang dilakukan dengan mengembangkan kurikulum program studi dan program kegiatan berbasis Merdeka Belajar- Kampus Merdeka. Hasil pengembangan kemudian ditindaklanjuti dengan rekapitulasi jumlah mahasiswa yang menjadi ukuran mutu MBKM dalam penelitian ini yakni dari 20 Program Studi di FKIP Universitas Jambi yang mengikuti program Asistensi Mengajar pada dasarnya setiap Mahasiswa pada Program Studi FKIP Universitas Jambi menunjukkan 17 PS di FKIP Universitas Jambi memiliki ketertarikan dalam mengikuti program kemtenterian tersebut. Hal ini dapat dilihat dari proporsi sebaran Mahsiswa yang mengikuti program tersebut $>5 \%$. Ini artinya kebijakan baru tersebut menjadi daya magis dan magnet sendiri bagi peserta didik di masa Pandemi Covid-19.

Jadi, dengan adanya kebijakan "Merdeka Belajar" harus dimaknai bukan hanya sebagai kesempatan bagi mahasiswa memiliki bidang sesuai kebutuhannya, melainkan juga merupakan kesempatan yang baik bagi para pengelola untuk bereksperimen melakukan berbagai terobosan dan mengundang partisipasi semua pihak melalui kerjasama simbiosis, atau para dosen untuk berinovasi dalam pengelolaan pembelajaran(Baharuddin, 
5260 Pengukuran Mutu Pembelajaran di FKIP UNJA dalam Upaya Membangun Generasi Economic Citizen yang Mengelaborasi Program MBKBM Kemendikbud - Rosmiati, Iwan Putra, Ahmad Nasori

DOI: https://doi.org/10.31004/edukatif.v3i6.1356

2021; Rahmawati \& Susilowati, 2021; Susanty, 2020)

Berikut mengenai proporsi sebaran presentasi seberan mengengai kegiatan MBKM yang diikuti oleh Program Studi yang ada di FKIP Universitsa Jambi yakni menujukkan Jumlah mahasiswa FKIP Universitas Jambi Tahun ajaran 2021 yang berhak mendapatkan pengakuan kredit 20 SK dari KM2 = 313 Mahasiswa (IKU2). Oleh karena itu, Kewajiban Program studi adalah 1) Merumuskan skema konversi sebanyak 20 SKS bagi Peserta Semester 5; 2) Memprioritaskan konversi pada mata kuliah Wajib Program Studi yang ada di Semester 5,6, dan 7; 3)Pola yang sama dapat digunakan untuk pengakuan kredit PHP2D dan kegiatan MBKM lainnya; 4) Mendukung mahasiswa secara penuh dalam pelaksanaan program KM 2 dan MBKM lainnya

Dengan adanya stus pembaharuan dari perubahan kurikulum yang terjadi tentu harus disertakan dengan semangat perubahan yang sama dimana hal tersebut bukan hanya berasal dari makro (PT dan PS), namun juga berasal dari mikro (mahasiswa). Oleh karena itu, perlu kajian mengenai kesiapan pelaksanaan adanya MBKM ini. Penjelasan mengenai gambaran mengenai persepsi Mahasiswa di FKIP Universitas Jambi mengenai adanya Penerapan MBKM pada kurikulum di Program Studi mereka dapat digambarkan sebagai berikut:

Tabel 2

Hasil Persepsi Mahasiswa Tentang Kurikulum MBKM

\begin{tabular}{cccccr}
\hline Rekognisi & SS & S & TS & \multicolumn{1}{c}{ STS } & \multirow{2}{*}{ Total } \\
\cline { 1 - 5 } MBKM & F\% & F\% & F\% & F\% & \\
\cline { 1 - 5 } $\mathbf{1}$ & 146 & 98 & 43 & 26 & 313 \\
\hline $\mathbf{2}$ & 46,65 & 31,31 & 13,74 & 8,31 & 100 \\
\hline & 100 & 161 & 35 & 17 & 313 \\
\hline $\mathbf{3}$ & 31,95 & 51,44 & 19,23 & 5,43 & 108,0487 \\
\hline & 138 & 110 & 65 & 0 & 313 \\
\hline
\end{tabular}

Rekognisi MBKM

1. Perkuliahan di PS lain di PT sendiri

2. Perkuliahan di PS sama di luar PT

3. Perkuliahan di PS lain di luar PT

4. Pembelajaran di lembaga nonperguruan tinggi

Tabel tersebut menunjukkan bagaimana para mahasiswa menanggapi kurikulum MBKM. Pada prinsipnya, MBKM menawarkan pilihan kepada mahasiswa untuk meningkatkan kemampuannya di bidang tertentu terutama berkaitan dengan lintas disiplin ilmu dan kesiapan mahasiswa dalam memasuki dunia kerja. Oleh karena itu, MBKM merupakan hak mahasiswa untuk mendapatkan rekognisi mata kuliah (Structure Form) atau CPL (Free Form) (Suryaman, 2020).

Untuk mendapatkan rekognisi ini maka mahasiswa diperkenankan untuk mengikuti perkuliahan di PS lain pada PT yang sama. Hal ini terjadi jika mata kuliah yang ada diprodi belum memaksimalkan potensi yang dimiliki mahasiswa.

Dari pola penerapan kurikulum MBKM di FKIP Universitsa Jambi ini mengenai kegiatan Asistensi Mengajar, mayoritas mahasiswa menjawab bahwa 46,65\% orang sangat setuju dalam melaksanakan pembelajaran kuliah melalui Asistensi Mengajar. Sedangkan, sebagian mahasiswa lainnya yakni menjawab $31,31 \%$ setuju, $13,74 \%$ tidak setuju, dan $8,31 \%$ sangat tidak setuju. Berikut uraian penjelasan mengenai proporsi tersebut yakni sebagai berikut: 


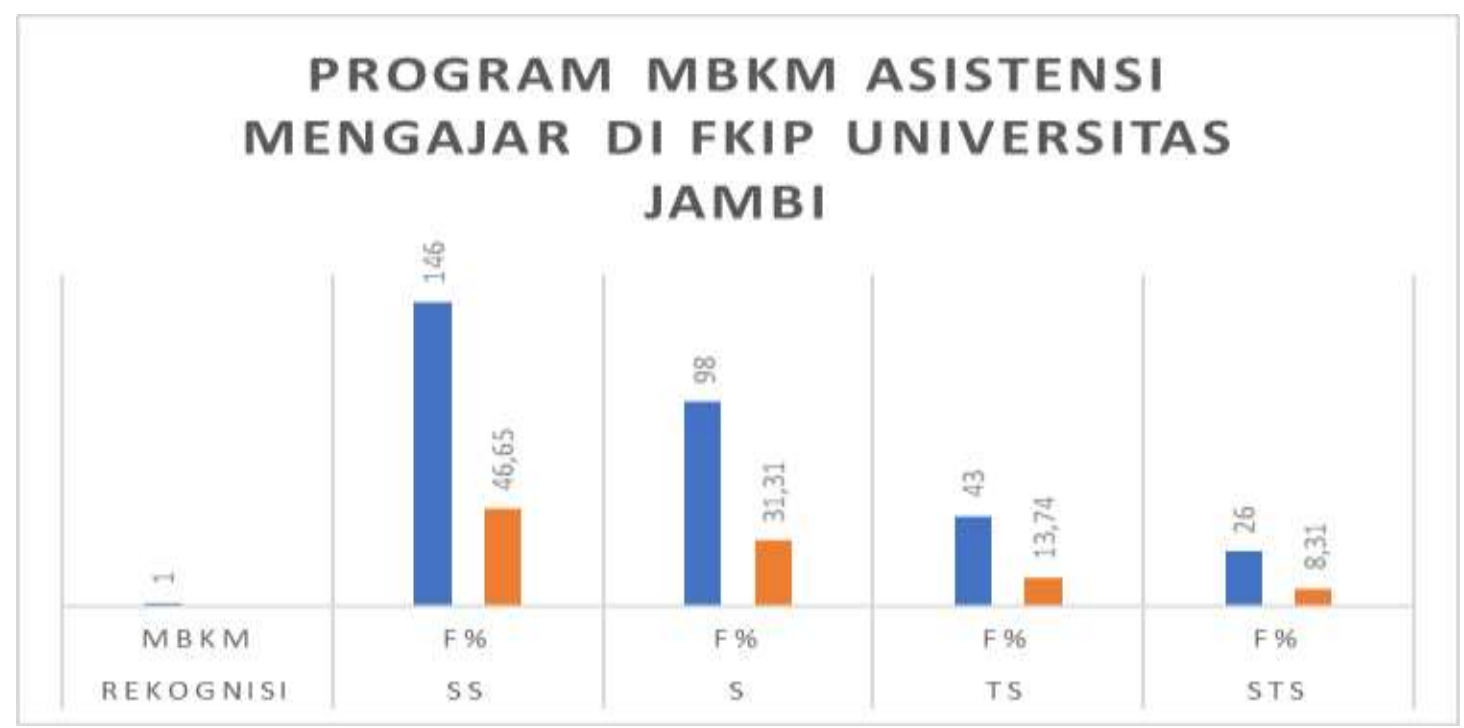

Gambar 3. Hasil Persepsi Mahasiswa FKIP UNJA MBKM Asistensi Mengajar

Kegiatan MBKM di FKIP Universitas Jambi yang diikuti oleh mahasiswa berikutnya yakni adalah membangun Desa melalui Kegiatan PHP2D. Program MBKM tersebut juga menunjukan juga mutu pembelajara dalam implementasi MBKM juga tergolong tinggi, hal ini terlihat pada persepsi mahasiswa dalam mengikuti program tersebut yakni tergambar sebagai berikut:

\section{PROGRAM MBKM DI FKIP UNJA MEMBANGUN DESA MELALUI PHP2D}

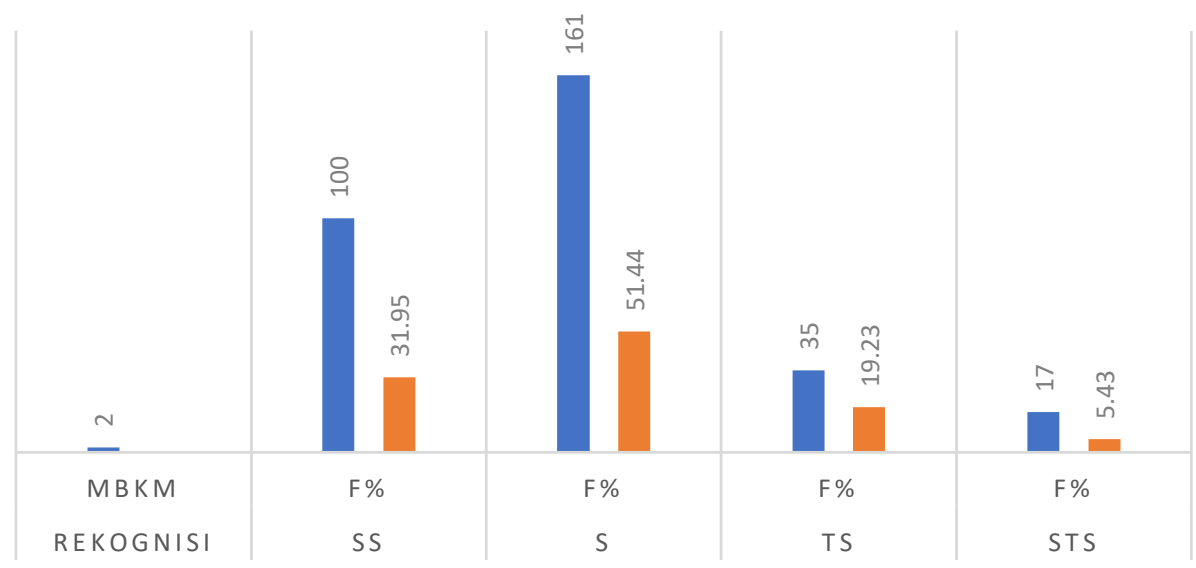

\section{Gambar 4. Hasil Persepsi Mahasiswa tentang Program MBKM Membangun Desa melalui PHP2D di FKIP UNJA}

Program MBKM membangun desa melalui kegiatan PHP2D yang diikuti oleh mahasiswa di FKIP Universitas Jambi yang mengindakasikan respons yang positi mengenai kegiatan tersebut. Respon positif tersebut ditunjukkan melalui persepsi pengukuran mutu pembelajaran dari kegiatan MBKM yang diikuti Mahasiswa FKIP Universitas Jambi menunjukkan sebanyak 100 orang atau31,95\% sangat setuju mengenai penerapan kegiatan tersebut, sedangkan 161 orang atau 51,44\% setuju dengan kegiatan tersebut, untuk yang tidak setuju hanya 35 orang atau 19,23\% dan yang sangat tidak setuju hanya 17 orang atau 5,43\%. Untuk program MBKM yang diikuti oleh Mahasiswa FKIP Universitas Jambi berikutnya ialah pertukaran pelajar. 

yang Mengelaborasi Program MBKBM Kemendikbud - Rosmiati, Iwan Putra, Ahmad Nasori

DOI: https://doi.org/10.31004/edukatif.v3i6.1356

Berikut rekapitulasi persepsi mahasiswa mengenai kegiatan yang diselenggaran tersebut yakni sebagai berikut:

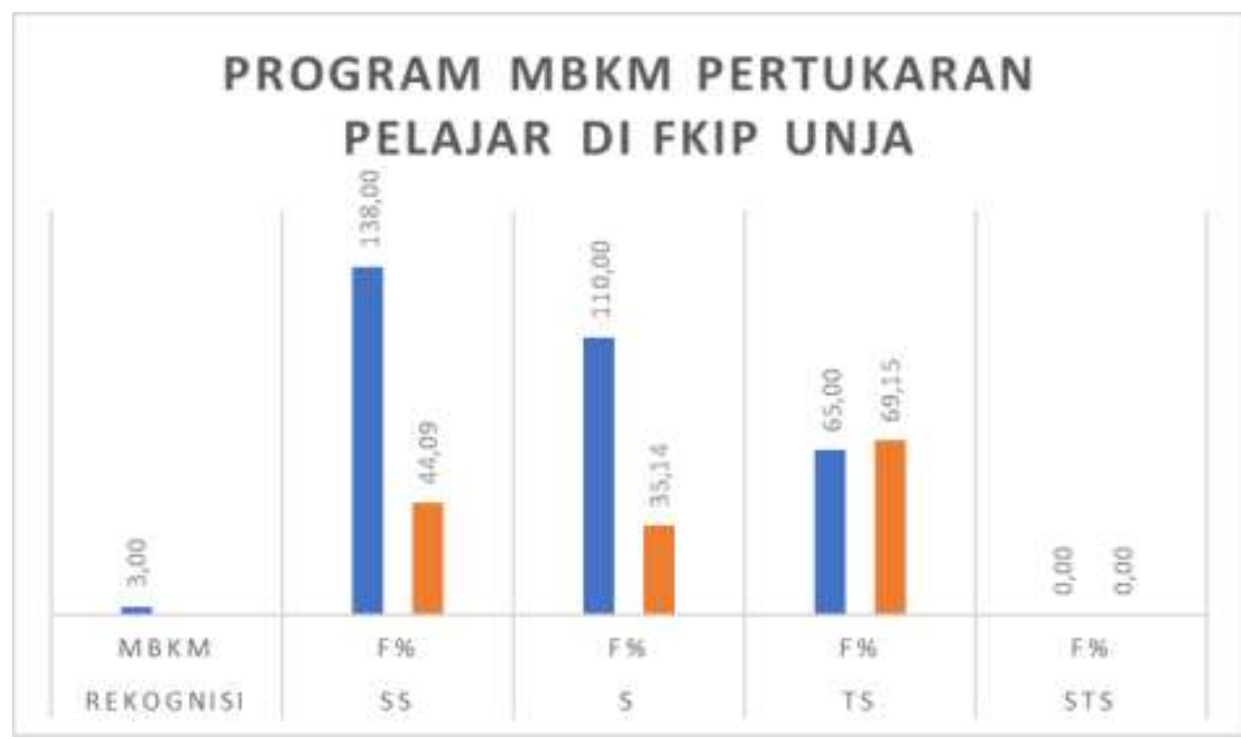

Gambar 5. Hasil Persepsi Mahasiswa tentang Pertukaran Pelajar

Rekognisi terakhir dari MBKM adalah mahasiswa dapat melakukan Perukran pelajara dengan mahaiswa lainnya dari Program Studi lain atau dari PT lainnya. Hal ini dapat dilakukan oleh mahasiswa yang ingin perkuliahannya langsung di lapangan pekerjaaan pada PS atau PT yang bermitra dan memiliki kurikulum yang sama dengan PS mahasiswa itu sendiri .

Berdasarkan hasil jawaban 313 orang mahasiswa di FKIP Universitas Jambi yang mengikuti Program MBKM tersebut, mayoritas mahasiswa, yaitu 44,09 sangat setuju terhadap rekognisi untuk pertukaran pelajar, 35,14\% menyatakan etuju, dan 69,15 tidak setuju. Hal ini menunjukkan kurang antusias dari mahasiswa terkait dengan program rekognisi ini.

Meskipun data menunjukkan mayoritas mahasiswa setuju untuk mengikuti program MBKM namun terlihat gaap yang besar pada mahasiswa paradigma lama dengan hanya puas menekuni satu bidang yang sesuai dengan jurusannya meskipun ada tawaran mengenai kegiatan pertukaran pelajar, factor kesipan belajar, mental berkompetisi dan ekonomi menjadi alasan bagi mahasiswa di FKIP Universitsa Jambi. Oleh karena munculnya keragaman sikap ini, maka MBKM dapatdilaksanakan sesuai dengan kebutuhan mahasiswa. Yang lebih penting, program studi memfasilitasi MBKM ini untuk dapat diakses oleh semua mahasiswa.

\section{KESIMPULAN}

Secara massif dan kuantitatif persepsi mahasiswa mengenai mutu pembelajaran dari penerapan MBKM di FKIP Universeitas Jambi pada dasarnya baik hal ini ditandai dengan keikutsertaan 17 Program Studi yang ada di FKIP Universitas Jambi dalam menstimulus peserta didiknya dalam mengikuti program tersebut. Salah satu upaya yang dilakukan adalah dengan memberikan ruang yang seluas-luasnya bagi potensi para mahasiswa untuk dapat dikembangkan sesuai dengan kebutuhan zamannya dengan program MBKM ini. Persepsi mahasiswa pun positif terhadap MBKM ini, hal ini ditandai dengan tingkat persetujuan para mahasiswa terhadap rekognisi yang ada di dalam MBKM. Artinya para mahasiswa pun siap untuk melakukan perubahan dalam dirinya. Dengan demikian, MBKM bisa jadi jawaban dari permasalahan yang sering muncul pada lulusan yang sering mengalami jarak dengan dunia usaha. 
5263 Pengukuran Mutu Pembelajaran di FKIP UNJA dalam Upaya Membangun Generasi Economic Citizen yang Mengelaborasi Program MBKBM Kemendikbud - Rosmiati, Iwan Putra, Ahmad Nasori

DOI: https://doi.org/10.31004/edukatif.v3i6.1356

\section{UCAPAN TERIMA KASIH}

Penulis mengucapkan terimakasih kepada pihak yang telah terlibat langsung dalam penelitian ini. Peneliti juga mengucapkan terimakasih kepada pihak-pihak lainnya yang telah membantu keberlangsungan penelitian ini, terutama kepada Rektor Universitas jambi, Dekan FKIP Universitas Jambi, Ketua Jurusan PIPS, Kaprodi pendidikan Ekonomi dan Seluruh dosen Pendidikan Ekonomi FKIP Universitas Jambi hingga penelitian ini berjalan dengan lancar

\section{DAFTAR PUSTAKA}

A, J. C., B, K. B., C, J. R., D, B. M., E, M. G., G, P. A. M., \& H, S. L. (2020). Journal of Applied Learning \& Teaching COVID-19: 20 countries' higher education intra-period digital pedagogy responses. Journal of Applied Learning \& Teaching, 3(1).

Arora, M., Goyal, L. M., Chintalapudi, N., \& Mittal, M. (2020). Factors affecting digital education during COVID-19: A statistical modeling approach. Proceedings of the 2020 International Conference on Computing, Communication and Security, ICCCS 2020. https://doi.org/10.1109/ICCCS49678.2020.9277370

B, K. A. A. G. (2020). Novel coronavirus (COVID-2019) pandemic: Common challenges and response from higher education providers. Journal of Applied Learning \& Teaching, 2(2). https://doi.org/10.37074/jalt.2020.3.2.20

Baharuddin, M. R. (2021). Adaptasi Kurikulum Merdeka Belajar Kampus Merdeka (Fokus: Model MBKM Program Studi). Jurnal Studi Guru Dan Pembelajaran, 4(1), 195-205.

Bethlehem, J. (2009). Applied Survey Methods. Applied Survey Methods. https://doi.org/10.1002/9780470494998

Dutta, D. A. (2020). Impact of Digital Social Media on Indian Higher Education: Alternative Approaches of Online Learning during COVID-19 Pandemic Crisis. International Journal of Scientific and Research Publications (IJSRP), 10(05), 604-611. https://doi.org/10.29322/ijsrp.10.05.2020.p10169

Dzisah, J., \& Etzkowitz, H. (n.d.). Triple Helix Circulation: The Heart of Innovation and Development.

Halaby, C. N. (1994). Overeducation and Skill Mismatch. Sociology of Education, 67(1), 47. https://doi.org/10.2307/2112749

Hox, J., \& Dillman, D. A. (2012). International Handbook of Survey Methodology. International Handbook of Survey Methodology, (May 2020). https://doi.org/10.4324/9780203843123

Iivari, N., Sharma, S., \& Ventä-Olkkonen, L. (2020). Digital transformation of everyday life - How COVID19 pandemic transformed the basic education of the young generation and why information management research should care? International Journal of Information Management, 55(June), 102183. https://doi.org/10.1016/j.ijinfomgt.2020.102183

Maity, S., Sahu, T. N., \& Sen, N. (2021). Panoramic view of digital education in COVID-19: A new explored avenue. Review of Education, 9(2), 405-423. https://doi.org/10.1002/rev3.3250

Martín, C. T., Acal, C., Honrani, M. El, \& Estrada, Á. C. M. (2021). Impact on the virtual learning environment due to covid-19. Sustainability (Switzerland), 13(2), 1-16.

https://doi.org/10.3390/su13020582

Pastore, F., \& Zimmermann, K. F. (2019). Contributions to school-to-work transitions: vocational training, skill mismatch and policy. International Journal of Manpower, 40(8), 1361-1363. https://doi.org/10.1108/IJM-11-2019-420

Pellizzari, M., \& Fichen, A. (2017). A new measure of skill mismatch: theory and evidence from PIAAC. IZA Journal of Labor Economics, 6(1), 1-30. https://doi.org/10.1186/s40172-016-0051-y

Rahmawati, A. N., \& Susilowati, L. (2021). Implementasi Kebijakan Merdeka Belajar. Jurnal Sosial Ekonomi 
5264 Pengukuran Mutu Pembelajaran di FKIP UNJA dalam Upaya Membangun Generasi Economic Citizen yang Mengelaborasi Program MBKBM Kemendikbud - Rosmiati, Iwan Putra, Ahmad Nasori

DOI: https://doi.org/10.31004/edukatif.v3i6.1356

Dan Politik, 2(4), 59-66. Retrieved from http://www.jsep.org/index.php/jsep/index

Ratten, V., \& Jones, P. (2021). Covid-19 and entrepreneurship education: Implications for advancing research and practice. International Journal of Management Education, 19(1), 100432. https://doi.org/10.1016/j.ijme.2020.100432

Sá, M. J., \& Serpa, S. (2020). COVID-19 and the promotion of digital competences in education. Universal Journal of Educational Research, 8(10), 4520-4528. https://doi.org/10.13189/ujer.2020.081020

Senkrua, A. (2021). A Review Paper on Skills Mismatch in Developed and Developing Countries. International Journal of Sustainable Development \& World Policy, 10(1), 8-24. https://doi.org/10.18488/journal.26.2021.101.8.24

Susanty, S. (2020). Inovasi Pembelajaran Daring Dalam Merdeka Belajar. Jurnal Ilmiah Hospitality, 9(2), 157-166. https://doi.org/10.47492/jih.v9i2.289

Wright, C. C. (2020). COVID-19 Pandemic and the Digital Revolution. ASA Monitor, 84(8), 30-30. https://doi.org/10.1097/01.m99.0000695184.52961.46 